\title{
Homocysteine-induced oxidative stress upregulates chymase in mouse mastocytoma cells
}

\author{
Kanta Fujimi $^{1}$, Yoshinari Uehara ${ }^{1}$, Satomi Abe ${ }^{1}$, Akira Kawamura $^{1}$, Sankar Devarajan ${ }^{2}$, Shin-ichiro Miura ${ }^{1}$, \\ Keijiro Saku ${ }^{1}$ and Hidenori Urata ${ }^{2}$
}

Reactive oxygen species (ROS) such as hydrogen peroxide $\left(\mathrm{H}_{2} \mathrm{O}_{2}\right), \mathrm{O}_{2}^{--}$and $\mathrm{OH}^{\circ}$ participate in the pathogenesis of ischemia/ reperfusion injury, inflammation and atherosclerosis. Our previous studies have suggested that increased angiotensin II (Ang II)forming chymase may be involved in the development of atherosclerosis. However, the regulatory mechanism of chymase expression has not yet been clarified. In this study, we tested whether oxidative stress upregulates mouse mast cell proteinase chymase, mouse mast cell proteinase (MMCP)-5 or MMCP-4. We also examined the expression and activity of these proteins after treatment. Cultured mouse mastocytoma cells (MMC) displaying chymase-dependent Ang II-forming activity were treated with $\mathrm{H}_{2} \mathrm{O}_{2}$ and several aminothiols with or without anti-oxidants. The levels of MMCP-5 and MMCP-4 expression were determined by quantitative RT-PCR; the level of chymase-dependent Ang II-forming activity was measured by high performance liquid chromatography using Ang $I$ as a substrate. Treatment of MMC with homocysteine $\left(0.1-3 \mathrm{mmol}^{-1}\right)$ significantly increased MMCP-5 and MMCP-4 expression, as well as Ang II-forming activity. These effects were significantly inhibited by the addition of catalase and further suppressed by the combination of catalase and superoxide dismutase. Incubation with hydrogen peroxide alone caused a significant increase in Ang II-forming activity, which was completely suppressed by co-treatment with catalase. Furthermore, MMCP-5 and MMCP-4 expression levels were drastically suppressed and chymase induction by homocysteine was diminished under the GATA-inhibited condition. Homocysteine increased mast cell chymase expression and activity through the mechanism of oxidative stress. Our results suggest that there is a biochemical link between oxidative stress and the local Ang IIforming system.

Hypertension Research (2010) 33, 149-154; doi:10.1038/hr.2009.205; published online 4 December 2009

Keywords: angiotensin II; chymase; homocysteine; mast cell; reactive oxygen species

\section{INTRODUCTION}

Reactive oxygen species (ROS) such as hydrogen peroxide $\left(\mathrm{H}_{2} \mathrm{O}_{2}\right)$, superoxide anion $\left(\mathrm{O}_{2}^{\bullet-}\right)$, and hydroxyl radical $\left(\mathrm{OH}^{\bullet}\right)$ participate in the development of atherosclerosis. Many cells that comprise the vasculature generate ROS. These molecules are generally thought to be harmful to the vasculature and lead to pathological processes such as hypertension, restenosis and atherosclerosis. Several studies have provided clear evidence that vascular disorders, including atherosclerosis, at least in part result from the presence of these ROS. ${ }^{1}$ Several aminothiols, including homocysteine and cysteine, can promote atherogenesis by virtue of their effects on endothelial function, vascular smooth muscle cell activation and hemostatic activation. ${ }^{2-8}$ These aminothiols have a critical role as intracellular redox buffers, and it is also becoming increasingly recognized that they comprise an important extracellular redox system. ${ }^{9,10}$ It has also been reported that homocysteine exerts its detrimental effects in part through a mechanism involving oxidative stress. ${ }^{11,12}$
The renin-angiotensin system has an important role in the development of cardiovascular diseases. In addition to previously known pathological effects of angiotensin II (Ang II), recent studies have shown that Ang II induces superoxide overproduction, which promotes the proliferation of vascular smooth muscle cells, lipid peroxidation, inactivation of nitric oxide and stimulation of adhesion molecule expression. ${ }^{13,14}$ These direct and indirect effects of Ang II appear to contribute to the formation of atherosclerotic lesions. Several recent studies have shown the existence of an alternative Ang II-forming pathway, independent of ACE. Several serine proteinases, such as chymase, kallikrein and cathepsin G, are probably responsible for ACE-independent Ang II-forming activity in human tissue. ${ }^{15}$ Among them, chymase is the most abundant, and its immunoreactivity is observed primarily in the secretory granules of mast cells. Our preliminary experiment revealed that mouse mastocytoma cells (MMC) used in this study expressed mRNA for mouse mast cell proteinase (MMCP)-5, which is known to

${ }^{1}$ Department of Cardiology, Fukuoka University Faculty of Medicine, Jonan-ku, Fukuoka, Japan and ${ }^{2}$ Department of Cardiovascular Diseases, Fukuoka University Chikushi Hospital, Chikushino, Fukuoka, Japan

Correspondence: Dr Y Uehara, Department of Cardiology, Fukuoka University Faculty of Medicine, 7-45-1 Nanakuma, Jonan-ku, Fukuoka 814-0180, Japan.

E-mail: ueharay@fukuoka-u.ac.jp

Received 24 April 2009; revised 5 September 2009; accepted 27 October 2009; published online 4 December 2009 
enzymatically cleave Ang I to Ang II. ${ }^{16}$ We did not detect mRNA for MMCP-1, 2 or L.

A mouse mastocytoma cell line, P815 MMC, was established from a mastocytoma in a DBf/2 mouse and can proliferate in the peritoneal cavity of the syngenic mouse. ${ }^{17}$ The P815 cell line has been reported to show constitutive phosphorylation on a tyrosine residue on the $c$-kit tyrosine kinase receptor in the absence of stimulation with stem cell factor. Furthermore, P815 MMC does not express the endogenous high-affinity multisubunit receptor for IgE, Fc epsilon receptor type I; Fc epsilon receptor type $\mathrm{I}$ is found only on mast cells and basophils. ${ }^{17,18}$ These observations indicate that P815 MMC has no similarity in terms of physiological properties to classical mast cells. However, P815 MMC can be induced to differentiate towards a mast cell-like phenotype, as shown by the activation described below.

Our previous reports show a strong positive association between hypercholesterolemia and arterial Ang II-forming chymase expression, ${ }^{19}$ which is further augmented in established atherosclerotic lesions. ${ }^{20}$ However, the detailed regulatory mechanism of chymase expression has not yet been clarified. In this study, we tested the existence of chymase-dependent Ang II-forming activity in P815 MMC. We also investigated whether oxidative stress upregulates mouse mast cell chymase expression and chymase-dependent Ang II-forming activity in cultured MMC and examined the effects of antioxidants such as superoxide dismutase (SOD) and catalase.

\section{METHODS}

\section{Materials}

DL-homocysteine, catalase, SOD, chymostatin and aprotinin were obtained from Sigma (St Louis, MO, USA). $\mathrm{H}_{2} \mathrm{O}_{2}$ was obtained from Mitsubishi Gas Chemical Company (Tokyo, Japan). A specific GATA inhibitor, K-11706, was purchased from Kowa Co. Ltd (Tokyo, Japan).

\section{Cell culture}

P815 MMC were obtained from the American Type Culture Collection (Manassas, VA, USA). MMC were maintained in Dulbecco's Modified Eagle's Medium (DMEM) supplemented with $1 \%$ fetal bovine serum. MMC were plated at a density of $1 \times 10^{5}$, harvested every $72 \mathrm{~h}$, and kept at $37^{\circ} \mathrm{C}$ in an atmosphere of $5 \% \mathrm{CO}_{2} /$ air. Catalase, SOD and GATA inhibition were initiated $30 \mathrm{~min}$ before incubation with homocysteine or hydrogen peroxide.

\section{Cell preparation and assessment of Ang II formation}

MMC were detached by a cell scraper in PBS, washed twice with PBS, and then placed in $50 \mathrm{mmoll}^{-1} \mathrm{NaH}_{2} \mathrm{PO}_{4}$ buffer, $\mathrm{pH} 7.4$, at $4{ }^{\circ} \mathrm{C}$. Harvested cells were homogenized with a glass/glass homogenizer and finally resuspended with the same buffer. The protein concentration of the cell homogenate was measured using Protein Assay Reagent (Pierce, Rockford, IL, USA). The extent of Ang II formation from Ang I was determined as described elsewhere, with some modifications..$^{21}$ The cells prepared as above were incubated with Ang I at $37{ }^{\circ} \mathrm{C}$ for $30 \mathrm{~min}$. The amount of Ang II formed was analyzed by reversed-phase highperformance liquid chromatography (HPLC) using a C18 reversed-phase column $(2.2 \times 25 \mathrm{~cm}$; Vydac, Hesperia, CA, USA) with a 15 -min linear acetonitrile gradient (3-13\%) in $25 \mathrm{mmoll}^{-1}$ triethylamine-phosphate buffer, $\mathrm{pH} 3$, at a flow rate of $2 \mathrm{ml} \mathrm{min}^{-1}$. Ang II-forming activity was expressed as nanomoles of Ang II formed per minute per milligram of protein. Chymostatin $\left(0.1 \mathrm{mmoll}^{-1}\right)$ -inhibitable and aprotinin $\left(0.24 \mathrm{mmoll}^{-1}\right)$-insensitive Ang II formation were expressed as chymase-dependent Ang II-forming activity (chymase-like activity). All analyses for each sample were performed in duplicate, and the reproducibility and quality of all data were confirmed before statistical analysis.

\section{Reverse-transcribed PCR}

Total RNA was extracted from cells in $9.6 \mathrm{~cm}^{2}$ dishes using the RNeasy kit (Qiagen, Hilden, Germany) according to the manufacturer's protocol. Cells were treated with DNase to remove residual contaminating DNA. The RNA was reverse-transcribed and cDNA was amplified by PCR using Superscript II reverse transcriptase and oligo-dT primers from Invitrogen (Carlsbad, CA, USA).

Conventional PCR. Gene-specific primers for conventional PCR were used as follows: MMCP-5 5'-CCAAAATATGATGAGAATTTGGTTGTCC-3' (forward), $5^{\prime}$-GGGGCTTTGCATTCCGATGTA-3' (reverse), annealing at $60^{\circ} \mathrm{C}$, $1.5 \mathrm{mmoll}^{-1} \mathrm{MgCl}_{2}$. The amplification conditions for MMCP-5 were $96^{\circ} \mathrm{C}$ for $30 \mathrm{~s}, 60^{\circ} \mathrm{C}$ for $30 \mathrm{~s}$ and $72{ }^{\circ} \mathrm{C}$ for $90 \mathrm{~s} ; 40$ cycles. PCR products were electrophoresed on $1.5 \%$ agarose gel, visualized with ethidium bromide and photographed. The proportions of MMCP- 5 and $\beta$-actin mRNA were determined by densitometric scanning ( $300 \AA$ Computing Densitometer and Image Quant Software v3.0 Fast Scan; Molecular Dynamics, Sunnyvale, CA, USA). The chymase mRNA levels were normalized to those of $\beta$-actin mRNA.

Real-time PCR. Gene-specific primers for real-time PCR were used as follows: MMCP-5 5'-CCTGTCTGTAGTTCCTGCTG- ${ }^{\prime}$ (forward), 5'-CAGTTGACAAT CTGGGTCTT- $3^{\prime}$ (reverse), MMCP-4 $5^{\prime}$-GCAGTCTTCACCCGAATCTC- ${ }^{\prime}$ (forward), 5'-CAGGATGGACACATGCTTTG-3' (reverse), GAPDH 5'-AACGA CCCCTTCATTGAC-3' (forward), 5'-TCCACGACATACTCAGCA-3' (reverse), annealing at $60^{\circ} \mathrm{C}, 1.5 \mathrm{mmoll}^{-1} \mathrm{MgCl}_{2}$. Human MMCP-4, MMCP-5 and GAPDH gene expression were quantified by real-time PCR using the Applied Biosystems GeneAmp 7500FAST sequence detection system (ABI, Foster City, CA, USA). Amplification was detected with SYBR Green as a fluorogenic probe specific for double-stranded DNA by using a QuantiTect SYBR Green PCR Kit (Qiagen). Threshold cycle, $C_{\mathrm{t}}$, which correlates inversely with the target mRNA level was measured as the cycle number at which the reporter's fluorescent emission increased above a threshold level. Melting curves were recorded and the size and specificity of PCR products were checked on $2 \%$ agarose gel. Only reactions that produced a single band of the expected size were used for analysis. Data analysis was performed using the $\Delta \Delta C_{\mathrm{t}}$ method.

\section{Transient transfections and reporter assays}

MMCs were transfected with $1 \mu \mathrm{g}$ of $\mathrm{p}(\mathrm{AP}-1)_{7}$-Luc plasmids and co-transfected with $5 \mathrm{ng}$ of pGL4.74 ( $h$ Rluc/TK) vector for the control (Renilla luciferase) by using Lipofectamine 2000 (Invitrogen). Lysates were assayed for luminescence intensity using the Dual-luciferase Assay System (Promega, Madison, WI, USA). AP-1 luciferase activity was divided by Renilla activity to obtain a normalized value: relative luciferase unit (RLU).

\section{Statistical analysis}

Data were analyzed using SAS enterprise guide 3.0 software (SAS Institute Inc., Cary, NC, USA). All data are presented as means \pm s.d. Differences between groups were evaluated by one-way analysis of variance. Significance level was set at $P<0.05$.

\section{RESULTS}

\section{Cell culture conditions}

The basic characteristics of cultured MMC were ascertained before the main study to determine the experimental conditions. Cultured MMC were originally floating cells. However, as the cell culture progressed, some MMC $(65 \pm 5 \%)$ attached to the bottom of the flask. The chymase-like activities of these two types of cells (floating and adhered) were measured separately on day 3 of culture. Chymasedependent Ang II-forming activity of adhered cells was significantly higher than that of floating cells. In addition, the effect of homocysteine on chymase-dependent Ang II-forming activity was more prominent in adhered cells than in floating cells. Based on these observations, the following analysis was performed only for adhered cells (data not shown).

\section{Effects of homocysteine on chymase-dependent Ang II-forming activity}

The time-course of homocysteine's effect on chymase-dependent Ang II-forming activity in MMC was determined. Chymase-dependent Ang II-forming activity in MMC significantly increased $12 \mathrm{~h}$ after the 
a
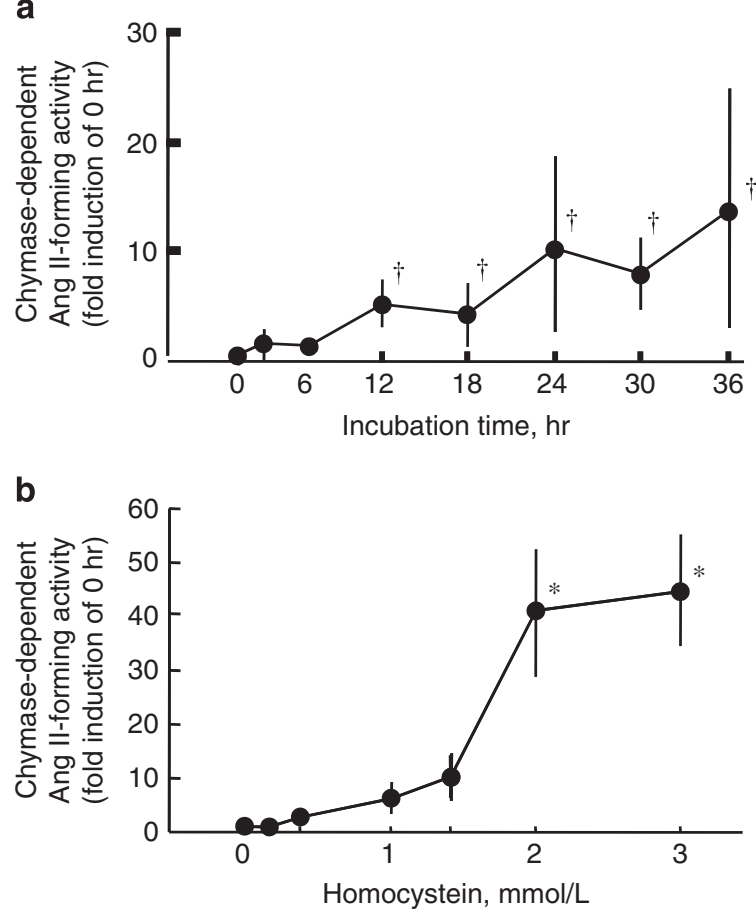

Figure 1 (a) Time-course of the effect of homocysteine on chymase activity in mouse mastocytoma cells (MMCs). MMCs were grown in DMEM. At the indicated times after the addition of $3 \mathrm{mmol}^{-1}$ homocysteine, chymasedependent Ang II-forming activity was measured by HPLC. Data are shown as mean \pm s.d. ( $n=4$ each). ${ }^{\dagger} P<0.01$ vs. $0 h$. (b) Dose-response of the homocysteine-induced increase in chymase-dependent Ang II-forming activity in MMCs. MMCs were incubated in DMEM. Homocysteine was then added at the indicated concentrations and the cells were incubated for another $24 \mathrm{~h}$. Chymase-dependent Ang II-forming activity was measured by HPLC. Data are shown as mean \pm s.d. $\left(n=4\right.$ each). ${ }^{*} P<0.001$ vs. $0 \mathrm{mmol}^{-1}$.

addition of homocysteine (Figure 1a). The effect of homocysteine on chymase-dependent Ang II-forming activity was dose-dependent at concentrations of 0.1 to $3 \mathrm{mmoll}^{-1}$. Chymase-dependent Ang IIforming activity in MMC treated with homocysteine (2 or $3 \mathrm{mmoll}^{-1}$ ) was significantly greater than that in non-stimulated control cells (Figure 1b). The effect of homocysteine on MMC chymase-dependent Ang II-forming activity was investigated. Incubation with homocysteine $\left(3 \mathrm{mmoll}^{-1}\right.$ for $\left.24 \mathrm{~h}\right)$ caused a significant increase in chymase-dependent Ang II-forming activity (37-fold at $3 \mathrm{mmoll}^{-1}$ homocysteine vs. control, $P<0.01$ ).

\section{Involvement of reactive oxygen species in the action} of homocysteine

The effect of $\mathrm{H}_{2} \mathrm{O}_{2}$ on MMC chymase-dependent Ang II-forming activity was investigated (Figure 2). Incubation with $\mathrm{H}_{2} \mathrm{O}_{2}$ alone $\left(250 \mu \mathrm{moll}^{-1}\right.$ for $\left.30 \mathrm{~min}\right)$ caused a significant increase in chymasedependent Ang II-forming activity $(n=9,28$-fold $v$ s. control, $P<0.01$ ), which was completely suppressed by co-treatment with catalase. Next, the effect of a radical scavenger was investigated. MMC were incubated with homocysteine $\left(3 \mathrm{mmoll}^{-1}\right)$ for $24 \mathrm{~h}$ with or without the radical scavenger catalase $\left(500 \mathrm{U} \mathrm{ml}^{-1}\right)$ or SOD $\left(200 \mathrm{U} \mathrm{ml}^{-1}\right)$. As shown in Figure 2, homocysteine-induced chymase-dependent Ang II-forming activity was inhibited by the addition of catalase alone $(n=9,78 \%$ less than the homocysteine group, $P<0.01$ ) and completely suppressed by the combination of catalase and SOD $(n=8, P=0.01)$.

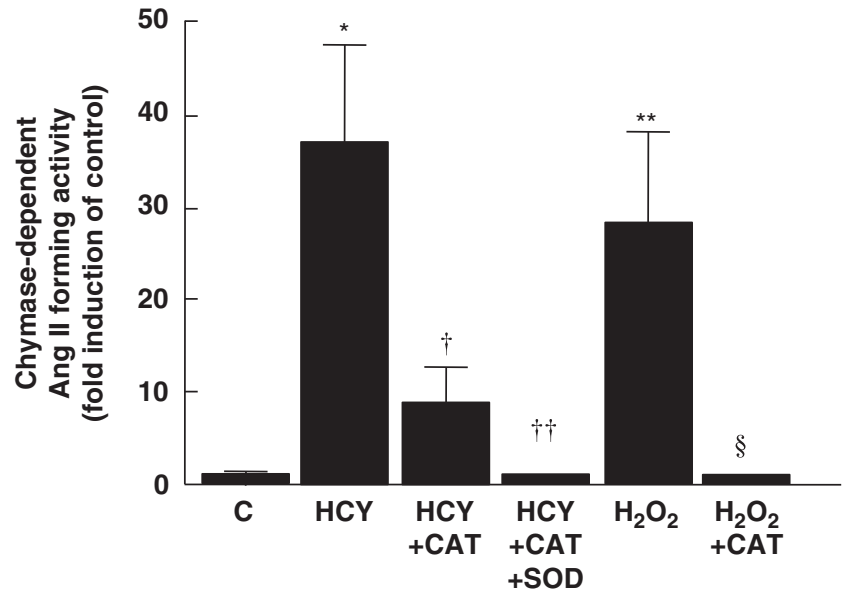

Figure 2 Effects of radical scavengers on the homocysteine- or hydrogen peroxidase-induced increase in chymase-dependent Ang II-forming activity in mouse mastocytoma cells (MMCs). MMCs were incubated with $500 \mathrm{U} \mathrm{ml}^{-1}$ catalase and/or $200 \mathrm{U} \mathrm{ml}^{-1}$ superoxide dismutase for $30 \mathrm{~min}$ before incubation with homocysteine and hydrogen peroxide. Then cells were given $3 \mathrm{mmol} \mathrm{I}^{-1}$ homocysteine and $250 \mu \mathrm{moll}^{-1}$ hydrogen peroxide. Data are shown as mean \pm s.d. ( $n=9$ each). ${ }^{*} P<0.001,{ }^{*} P<0.01$ vs. control; $\dagger P<0.01,{ }^{\dagger} P<0.001$ vs. $\mathrm{HCY} ;{ }^{\circledR} P<0.001$ vs. $\mathrm{H}_{2} \mathrm{O}_{2}$. CAT, SOD, HCY, $\mathrm{C}$ and $\mathrm{H}_{2} \mathrm{O}_{2}$ indicate catalase, superoxide dismutase, homocysteine, control and hydrogen peroxide, respectively.

mmcp-5

$\beta$-actin
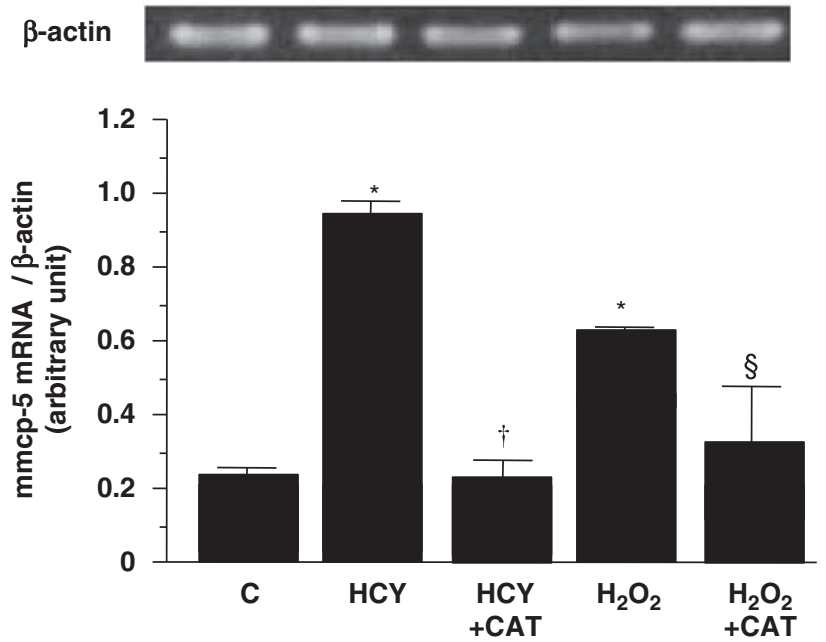

Figure 3 Effects of radical scavengers on homocysteine- or hydrogen peroxidase-induced MMCP-5 mRNA expression in MMCs. MMCs were incubated for $9 \mathrm{~h}$ with $500 \mathrm{U} \mathrm{ml}^{-1}$ catalase and/or $200 \mathrm{U} \mathrm{ml}^{-1}$ superoxide dismutase in the presence of $3 \mathrm{mmoll}^{-1}$ homocysteine, and $250 \mu \mathrm{mol} \mathrm{I}^{-1}$ hydrogen peroxide. MMCP-5 mRNA levels were normalized to those of $\beta$-actin mRNA. Data are shown as mean \pm s.d. ( $n=4$ each). ${ }^{*} P<0.01$ vs. control, ${ }^{\dagger} P<0.01$ vs. $\mathrm{HCY} ;{ }^{\S} P<0.05$ vs. $\mathrm{H}_{2} \mathrm{O}_{2}$. CAT, SOD, $\mathrm{HCY}, \mathrm{C}$ and $\mathrm{H}_{2} \mathrm{O}_{2}$ indicate catalase, superoxide dismutase, homocysteine, control and hydrogen peroxide, respectively.

\section{Effect of homocysteine on mouse chymase mRNA}

The effect of homocysteine on MMCP-5 mRNA expression was determined by semi-quantitative RT-PCR analysis (Figure 3). Homocysteine $\left(3 \mathrm{mmoll}^{-1}\right)$ was added at day 3 and MMC were harvested $9 \mathrm{~h}$ later. A significant upregulation of MMCP-5 mRNA 
was observed at $9 \mathrm{~h}$ after treatment with homocysteine $(n=4,4.0$-fold vs. control, $P<0.01)$. As shown in Figure 3, homocysteine-induced MMCP- 5 mRNA expression was inhibited by the addition of catalase alone ( $n=4,75 \%$ less than the homocysteine group, $P<0.01)$. The effects of $\mathrm{H}_{2} \mathrm{O}_{2}$ and a radical scavenger were investigated. Incubation with $\mathrm{H}_{2} \mathrm{O}_{2}$ alone caused a significant increase in MMCP-5 mRNA expression ( $n=4,2.6$-fold vs. control), which was suppressed by cotreatment with catalase $\left(n=4,47 \%\right.$ less than the $\mathrm{H}_{2} \mathrm{O}_{2}$ group, $P<0.05$ ) (Figure 3). Furthermore, the influence of the expression of mouse chymase in MMCP-4 and MMCP-5 was analyzed by quantitative RT-PCR. Homocysteine significantly increased both MMCP-4 and MMCP-5 mRNA expression, which displayed dose-dependent induction patterns (Figures $4 \mathrm{a}$ and $\mathrm{b}$ ). Interestingly, a GATA-specific inhibitor, K-11706, significantly suppressed both MMCP-4 and MMCP-5 expression. Moreover, the induction of mouse chymase expressions by homocysteine was attenuated in the presence of $\mathrm{K}$ 11706 (Figures 4c and d). Previous studies have shown that activator protein-1 (AP-1) is indispensable for transactivation of the IL-13 gene induced by GATA proteins in mast cells, ${ }^{22}$ and in mammalian systems, AP- 1 is involved in regulating the oxidative stress response. ${ }^{23}$ However, AP-1 is also strongly induced by some antioxidants such as $n$ acetyl cystein. ${ }^{24}$ In this study, exposure of mouse mastocytoma cells to homocysteine transiently transfected with AP-1 luciferase reporter plasmid showed increased AP-1 activity (Figure 5).

\section{DISCUSSION}

Mouse mast cells are classified as one of two subtypes: mucosal or connective tissue mast cells, both of which derive from common precursor cells. Mature mast cells retain more intracellular granules containing mast cell-specific proteases than do undifferentiated mast cells. In connective tissue mast cells, the main granular proteases are mast cell carboxypeptidase A (CPA), MMCP-4, MMCP-5 and MMCP-6. The expression of each mast cell protease changes during differentiation. ${ }^{25}$ A previous report showed that P815 MMC express CPA but no other mast cell proteases. However, when P815 MMC were injected

a

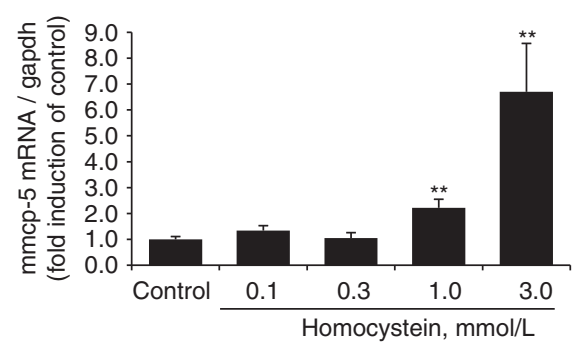

C

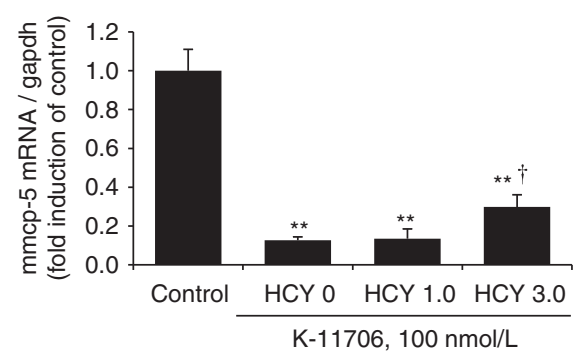

into the peritoneum of mice they started to express mast cell protease. ${ }^{26}$ As the present results suggest, activated adherent P815 MMCs displayed high levels of chymase-dependent Ang II-forming activity.

This study showed for the first time a direct positive association between ROS and increased mast cell chymase expression and activity. We previously showed a positive correlation between plasma LDLcholesterol levels and arterial chymase activity. ${ }^{19}$ Our present results showed that increased chymase expression and activity in vitro were caused by oxidative stress. Several ROS including $\mathrm{H}_{2} \mathrm{O}_{2}$ and $\mathrm{O}_{2}^{--}$are produced by vascular endothelium during reperfusion after ischemic injury. ${ }^{27,28}$ In addition, $\mathrm{O}_{2}^{\bullet-}$ can be generated by Ang II-mediated activation of NADH/NADPH oxidase by the AT1 receptor in VSM

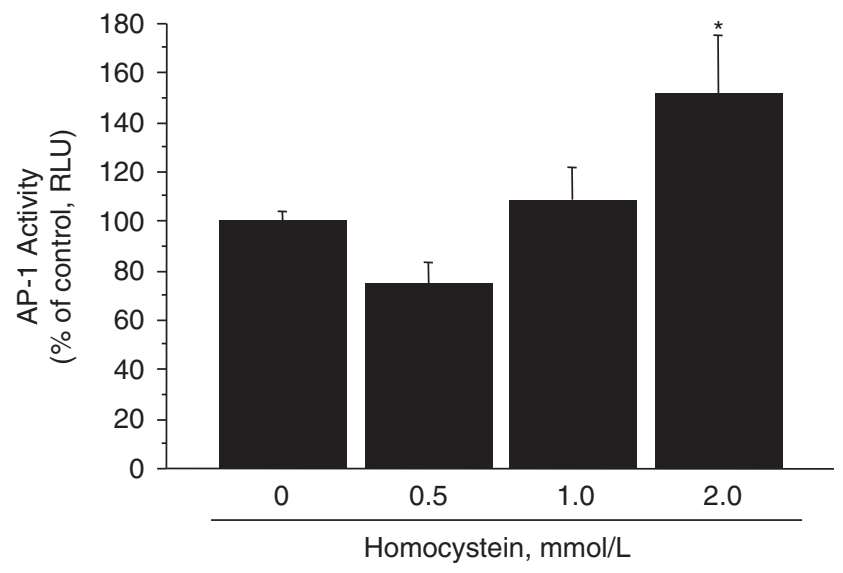

Figure 5 Involvement of AP-1 in the elevated level of chymase induced by homocysteine in MMCs. Native, p(AP-1) 7 -Luc reporter plasmid-transfected MCC were exposed for $6 \mathrm{~h}$ to homocysteine $\left(0-2.0 \mathrm{mmol} \mathrm{I}^{-1}\right)$. Lysates were assayed for luminescence intensity using the Dual-Luciferase Assay System (Promega). AP-1 luciferase activity was divided by Renilla activity to obtain a normalized value: relative luciferase unit (RLU). Data are shown as mean \pm s.d. $\left(n=7\right.$ each). ${ }^{*} P<0.01$, inhibitor-treated vs. untreated cells.

b

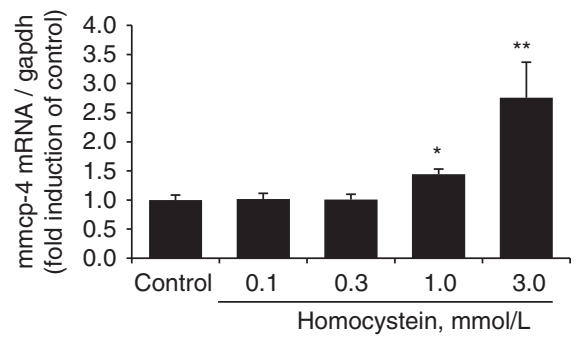

d

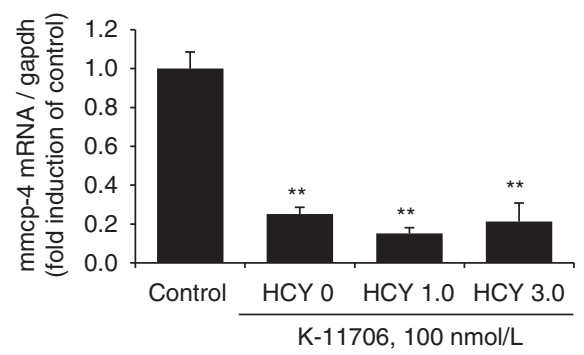

Figure 4 Effects of homocysteine (HCY) and a GATA-specific inhibitor on MMCP- 5 and MMCP-4 mRNA expression in MMCs. MMCs were incubated for $9 \mathrm{~h}$ with homocysteine (a-d) and K-11706, a specific GATA inhibitor (c and $\mathbf{d})$. MMCP-5 (a, $\mathbf{c}$ ) and MMCP-4 (b, d) mRNA levels were measured by real-time RT-PCR analysis. Data are shown as mean \pm s.d. ( $n=4$ each). ${ }^{*} P<0.05$ vs. control; ${ }^{* *} P<0.01$ vs. control, ${ }^{\dagger} P<0.05$ vs. untreated cells with homocysteine. 
cells, ${ }^{14,29}$ whereas $\mathrm{H}_{2} \mathrm{O}_{2}$ can be generated through the dismutation of $\mathrm{O}_{2}^{\bullet-}$, either spontaneously or by superoxide dismutase. ${ }^{30}$ These results strongly suggest that Ang II is important in initiating local ROS production. Therefore, it is quite interesting that an Ang II-forming serine protease, chymase, is upregulated by ROS, because this suggests that a vicious cycle is formed between ROS production and chymase expression. Chymase is thought to be associated with atherogenic processes, ${ }^{31}$ as a specific chymase inhibitor suppressed the development of high-cholesterol diet-induced atherosclerotic lesions in the hamster aorta. $^{32}$ Decreases in local Ang II production following treatment with a chymase inhibitor might reduce local ROS production, which could be an additional benefit that would in turn limit atherogenic changes. It is likely that chymase-mediated Ang II formation may have a proatherogenic role.

In this study, $\mathrm{H}_{2} \mathrm{O}_{2}$-induced increases in chymase-dependent Ang II-forming activity were completely abolished by catalase. However, homocysteine-induced increases in chymase-dependent Ang II-forming activity were incompletely inhibited by catalase and completely inhibited by SOD in combination with catalase. These results are derived from the different actions of each antioxidant. Both catalase and SOD are metalloproteins that catalyze 'dismutation' reactions, which detoxify $\mathrm{H}_{2} \mathrm{O}_{2}$ and $\mathrm{O}_{2}^{\bullet-}$, respectively. Namely, catalase catalyzes the formation of oxygen and water from two $\mathrm{H}_{2} \mathrm{O}_{2}$ molecules, whereas SOD catalyzes the formation of oxygen and $\mathrm{H}_{2} \mathrm{O}_{2}$ from two $\mathrm{O}_{2}^{\bullet-}$ molecules. ${ }^{33}$ Homocysteine-induced intracellular ROS formation yields not only $\mathrm{H}_{2} \mathrm{O}_{2}$ but also $\mathrm{O}_{2}^{\bullet-}$ and $\mathrm{OH}^{\bullet}$. Therefore, homocysteine-induced increases in chymase-dependent Ang II-forming activity might have been incompletely inhibited by catalase.

Oxygen-derived molecules have been linked to endothelial toxicity. ${ }^{34}$ Experiments in which cultured venous endothelial cells were exposed to homocysteine showed a major decrease in the adhesion of the cells to their substrate of tissue culture plastic. ${ }^{12,35}$ Similarly, when baboons were infused with homocysteine, substantial areas of vascular endothelium became desquamated, and this was followed by oxidative stress-induced atherogenic changes in the underlying vascular walls. ${ }^{35}$ Harker et al. ${ }^{36}$ suggested that homocysteine-induced cell injury results in the loss of endothelial cells followed by platelet adherence and release, as well as the development of progressive intimal atherosclerotic lesions.

Although several studies have provided evidence that various cytokines, such as $\mathrm{IL}-3^{37}$ and $\mathrm{IL}-4^{38}$ are involved in mast cell differentiation and the upregulation of chymase-dependent Ang IIforming activity, this study is the first to show that homocysteinederived oxidative stress upregulates chymase expression and activity. These findings are clinically relevant because it has been well documented that oxidative stress is increased in many cardiovascular diseases, ${ }^{39}$ including hypertension, ischemic heart disease, cardiomyopathy, myocarditis, heart failure and atherosclerosis. In fact, it has been reported that tissue chymase-dependent Ang II-forming activity is elevated in many cardiovascular diseases. ${ }^{31}$ In addition, ACE, another important Ang II-forming enzyme, is known to also be upregulated by oxidative stress ${ }^{40}$ and is elevated in many cardiovascular diseases. ${ }^{41}$ Therefore, Ang II formation is increased in cardiovascular diseases, at least in part because of oxidative stress, and the Ang II produced by ACE and/or chymase may have a role in organ damage and subsequent tissue remodeling. This concept has been supported by the results of recent clinical studies using ACE inhibitors or AT1-receptor antagonists in patients with acute myocardial infarction or congestive heart failure. ${ }^{42}$

The mechanisms of chymase upregulation by homocysteine and oxidative stress remain to be elucidated. Mast cells express high levels of GATA-1 and GATA-2. The role of GATA in chymase gene transcription has not been explored, ${ }^{43,44}$ but has previously been shown in P815 mast cells. ${ }^{45}$ Various studies suggested that AP-1, which is a dimeric complex of a Jun family protein and a Fos family protein, may functionally interact with GATA proteins. The Jun/Fos heterodimer was found to cooperate with GATA-2 in the transcription of endothelin- $1 .{ }^{46}$ Furthermore, the transcription of IL-13 is promoted by the direct interaction between GATA proteins and AP- 1 in mast cells. ${ }^{22}$ In this study, GATA inhibition drastically decreased chymase expression; moreover chymase induction by oxidative stress was diminished under the GATA-inhibited condition. These results suggest that ROS regulates chymase expression through the cooperative activation of GATA and AP-1.

This is the first study reporting that homocysteine and ROS increased mast cell chymase-dependent Ang II-forming activity. This study reveals that there is a linkage between ROS and the local mast cell-derived Ang II-forming system and that chymase may have a role in ROS-induced cell injury.

\section{ACKNOWLEDGEMENTS}

We thank Kowa Co. Ltd (Tokyo, Japan) for providing us with K-11706. This work was supported in part by grants-in-aid for Scientific Research (B; 13470153 and C; 19590874) from the Ministry of Education, Culture, Sports, Science and Technology of Japan to Dr Hidenori Urata and Dr Yoshinari Uehara, and in part by funds from the Central Research Institute of Fukuoka University to Dr Yoshinari Uehara.

1 Brigham KL. Role of free radicals in lung injury. Chest 1986; 89: 859-863.

2 Lentz SR, Sobey CG, Piegors DJ, Bhopatkar MY, Faraci FM, Malinow MR, Heistad DD. Vascular dysfunction in monkeys with diet-induced hyperhomocyst(e)inemia. J Clin Invest 1996; 98: 24-29.

3 Hofmann MA, Kohl B, Zumbach MS, Borcea V, Bierhaus A, Henkels M, Amiral J, Schmidt AM, Fiehn W, Ziegler R, Wahl P, Nawroth PP. Hyperhomocyst(e)inemia and endothelial dysfunction in IDDM. Diabetes Care 1998; 21: 841-848.

4 D'Angelo A, Selhub J. Homocysteine and thrombotic disease. Blood 1997; 90: 1-11.

5 Tsai JC, Perrella MA, Yoshizumi M, Hsieh CM, Haber E, Schlegel R, Lee ME. Promotion of vascular smooth muscle cell growth by homocysteine: a link to atherosclerosis. Proc Natl Acad Sci USA 1994; 91: 6369-6373.

6 Heinecke JW, Rosen H, Suzuki LA, Chait A. The role of sulfur-containing amino acids in superoxide production and modification of low density lipoprotein by arterial smooth muscle cells. J Biol Chem 1987; 262: 10098-10103.

7 Loscalzo J. The oxidant stress of hyperhomocyst(e)inemia. J Clin Invest 1996; 98: 5-7.

8 Hajjar KA. Homocysteine: a sulphrous fire. J Clin Invest 2001; 107: 663-664.

9 Munday R. Toxicity of thiols and disulphides: involvement of free-radical species. Free Radic Biol Med 1989; 7: 659-673.

10 Deneke SM. Thiol-based antioxidants. Curr Top Cell Regul 2000; 36: 151-180.

11 Upchurch Jr GR, Welch GN, Fabian AJ, Freedman JE, Johnson JL, Keaney Jr JF, Loscalzo J. Homocyst(e)ine decreases bioavailable nitric oxide by a mechanism involving glutathione peroxidase. J Biol Chem 1997; 272: 17012-17017.

12 Wall RT, Harlan JM, Harker LA, Striker GE. Homocysteine-induced endothelial cell injury in vitro: a model for the study of vascular injury. Thromb Res 1980; 18: 113-121.

13 Marui N, Offermann MK, Swerlick R, Kunsch C, Rosen CA, Ahmad M, Alexander RW, Medford RM. Vascular cell adhesion molecule-1 (VCAM-1) gene transcription and expression are regulated through an antioxidant-sensitive mechanism in human vascular endothelial cells. J Clin Invest 1993; 92: 1866-1874.

14 Griendling KK, Minieri CA, Ollerenshaw JD, Alexander RW. Angiotensin II stimulates NADH and NADPH oxidase activity in cultured vascular smooth muscle cells. Circ Res 1994; 74: 1141-1148.

15 Urata H, Kinoshita A, Misono KS, Bumpus FM, Husain A. Identification of a highly specific chymase as the major angiotensin II-forming enzyme in the human heart. J Biol Chem 1990; 265: 22348-22357.

16 Caughey GH, Raymond WW, Wolters PJ. Angiotensin II generation by mast cell alphaand beta-chymases. Biochim Biophys Acta 2000; 1480: 245-257.

17 Dunn TB, Potter M. A transplantable mast-cell neoplasm in the mouse. J Natl Cancer Inst 1957; 18: 587-601.

18 Rottapel R, Reedijk M, Williams DE, Lyman SD, Anderson DM, Pawson T, Bernstein A. The Steel/W transduction pathway: kit autophosphorylation and its association with a unique subset of cytoplasmic signaling proteins is induced by the Steel factor. Mol Cell Biol 1991; 11: 3043-3051. 
19 Uehara Y, Urata H, Sasaguri M, Ideishi M, Sakata N, Tashiro T, Kimura M, Arakawa K. Increased chymase activity in internal thoracic artery of patients with hypercholesterolemia. Hypertension 2000; 35: 55-60.

20 Ihara M, Urata H, Kinoshita A, Suzumiya J, Sasaguri M, Kikuchi M, Ideishi M, Arakawa $\mathrm{K}$. Increased chymase-dependent angiotensin II formation in human atherosclerotic aorta. Hypertension 1999; 33: 1399-1405.

21 Akasu M, Urata H, Kinoshita A, Sasaguri M, Ideishi M, Arakawa K. Differences in tissue angiotensin II-forming pathways by species and organs in vitro. Hypertension 1998; 32: $514-520$.

22 Masuda A, Yoshikai Y, Kume H, Matsuguchi T. The interaction between GATA proteins and activator protein-1 promotes the transcription of IL-13 in mast cells. J Immunol 2004; 173: 5564-5573.

23 Dalton TP, Li Q, Bittel D, Liang L, Andrews GK. Oxidative stress activates metal-responsive transcription factor-1 binding activity. Occupancy in vivo of metal response elements in the metallothionein-I gene promoter. J Biol Chem 1996; 271: 26233-26241.

24 Meyer M, Pahl HL, Baeuerle PA. Regulation of the transcription factors NF-kappa B and AP-1 by redox changes. Chem Biol Interact 1994; 91: 91-100.

25 Denburg JA. Basophil and mast cell lineages in vitro and in vivo. Blood 1992; 79 : $846-860$.

26 Ohtsu H, Kuramasu A, Suzuki S, Igarashi K, Ohuchi Y, Sato M, Tanaka S, Nakagawa S, Shirato K, Yamamoto M, Ichikawa A, Watanabe T. Histidine decarboxylase expression in mouse mast cell line P815 is induced by mouse peritoneal cavity incubation. J Biol Chem 1996; 271: 28439-28444.

27 Halliwell B. Reactive oxygen species in living systems: source, biochemistry, and role in human disease. Am J Med 1991; 91: 14S-22S.

28 Zweier JL, Broderick R, Kuppusamy P, Thompson-Gorman S, Lutty GA. Determination of the mechanism of free radical generation in human aortic endothelial cells exposed to anoxia and reoxygenation. J Biol Chem 1994; 269: 24156-24162.

29 Rajagopalan S, Kurz S, Munzel T, Tarpey M, Freeman BA, Griendling KK, Harrison DG. Angiotensin II-mediated hypertension in the rat increases vascular superoxide production via membrane NADH/NADPH oxidase activation. Contribution to alterations of vasomotor tone. J Clin Invest 1996; 97: 1916-1923.

30 Revak SD, Rice CL, Schraufstatter IU, Halsey Jr WA, Bohl BP, Clancy RM, Cochrane CG. Experimental pulmonary inflammatory injury in the monkey. J Clin Invest 1985; 76: 1182-1192.

31 Urata H. Pathological involvement of chymase-dependent angiotensin II formation in the development of cardiovascular disease. J Renin Angiotensin Aldosterone Syst 2000; 1: 35-37.

32 Uehara Y, Urata H, Ideishi M, Arakawa K, Saku K. Chymase inhibition suppresses highcholesterol diet-induced lipid accumulation in the hamster aorta. Cardiovasc Res 2002; 55: 870-876.
33 Zeng X, Dai J, Remick DG, Wang X. Homocysteine mediated expression and secretion of monocyte chemoattractant protein-1 and interleukin- 8 in human monocytes. Circ Res 2003; 93: 311-320.

34 Stamler JS, Osborne JA, Jaraki O, Rabbani LE, Mullins M, Singel D, Loscalzo J. Adverse vascular effects of homocysteine are modulated by endothelium-derived relaxing factor and related oxides of nitrogen. J Clin Invest 1993; 91: 308-318.

35 Harker LA, Slichter SJ, Scott CR, Ross R. Homocystinemia. Vascular injury and arterial thrombosis. N Engl J Med 1974; 291: 537-543.

36 Harker LA, Ross R, Slichter SJ, Scott CR. Homocystine-induced arteriosclerosis. The role of endothelial cell injury and platelet response in its genesis. J Clin Invest 1976; 58: 731-741.

37 Ihle JN, Keller J, Oroszlan S, Henderson LE, Copeland TD, Fitch F, Prystowsky MB, Goldwasser E, Schrader JW, Palaszynski E, Dy M, Lebel B. Biologic properties of homogeneous interleukin 3. I. Demonstration of WEHI-3 growth factor activity, mast cell growth factor activity, $\mathrm{p}$ cell-stimulating factor activity, colony-stimulating factor activity, and histamine-producing cell-stimulating factor activity. J Immunol 1983; 131: 282-287.

38 Toru H, Eguchi M, Matsumoto R, Yanagida M, Yata J, Nakahata T. Interleukin-4 promotes the development of tryptase and chymase double-positive human mast cells accompanied by cell maturation. Blood 1998; 91: 187-195.

39 Singal PK, Khaper N, Palace V, Kumar D. The role of oxidative stress in the genesis of heart disease. Cardiovasc Res 1998; 40: 426-432.

40 Ikemoto F, Song G, Tominaga M, Yamamoto K. Oxidation-induced increase in activity of angiotensin converting enzyme in the rat kidney. Biochem Biophys Res Commun 1988; 153: $1032-1037$.

41 Diet F, Pratt RE, Berry GJ, Momose N, Gibbons GH, Dzau VJ. Increased accumulation of tissue ACE in human atherosclerotic coronary artery disease. Circulation 1996; 94 : 2756-2767.

42 Cohn JN, Tognoni G. A randomized trial of the angiotensin-receptor blocker valsartan in chronic heart failure. N Engl J Med 2001; 345: 1667-1675.

43 Harigae H, Takahashi S, Suwabe N, Ohtsu H, Gu L, Yang Z, Tsai FY, Kitamura Y, Engel JD, Yamamoto M. Differential roles of GATA-1 and GATA-2 in growth and differentiation of mast cells. Genes Cells 1998; 3: 39-50.

44 Zon LI, Gurish MF, Stevens RL, Mather C, Reynolds DS, Austen KF, Orkin SH. GATAbinding transcription factors in mast cells regulate the promoter of the mast cell carboxypeptidase A gene. J Biol Chem 1991; 266: 22948-22953.

45 Liao Y, Yi T, Hoit BD, Walsh RA, Karnik SS, Husain A. Selective reporter expression in mast cells using a chymase promoter. J Biol Chem 1997; 272: 2969-2976.

46 Kawana M, Lee ME, Quertermous EE, Quertermous T. Cooperative interaction of GATA-2 and AP1 regulates transcription of the endothelin-1 gene. Mol Cell Biol 1995; 15: $4225-4231$. 